Absolute evil, radical evil, banality of evil.

The understanding of evil in Hannah Arendt

\title{
Mal absoluto, mal radical, banalidad del mal. La comprensión del mal en Hannah Arendt
}

\author{
Javier Leiva Bustos \\ Personal Docente e Investigador en Formación de la UAM \\ jleiva.1990@gmail.com \\ DOI: https://doi.org/10.15366/bp2019.22.002 \\ Bajo Palabra. II Época. No 22. Pgs: 57-80
}


Recibido: 14/06/2016

Aprobado: 02/10/2019

\section{Resumen}

En el siguiente artículo se pretende exponer una panorámica general del pensamiento de Hannah Arendt acerca de la cuestión del mal. Para ello estudiaremos brevemente el planteamiento de Kant sobre el "mal radical", que resultó de enorme influencia para la propia Arendt. Posteriormente observaremos la posición que mantuvo la pensadora en Los orígenes del totalitarismo y el cambio de enfoque que supuso la obra Eichmann en Jerusalén con el término "banalidad del mal". Por último, abogaremos por una continuidad y compatibilidad entre ambas posturas.

Palabras clave: banalidad del mal, Hannah Arendt, Kant, mal radical, totalitarismo.

\section{Abstract}

The aim of this article is to provide a panoramic exposition of Hannah Arendt's thought about the issue of evil. In order to achieve this task, I will pose briefly Kant's approach of 'radical evil', which had an enormous relevance for Arendt. Then, I will point out the stance held by her in The Origins of Totalitarianism and later to explain the way Arendt changed her mind after Eichmann in Jerusalem, particularly through the term 'banality of evil'. Finally, I advocate that both notions constitute not only a continuity but also they are compatible each other.

Keywords: banality of evil, Hannah Arendt, Kant, radical evil, totalitarianism. 


\section{Introducción}

Hannah Arendt tuvo la desgracia de vivir en primera persona la injusticia y la crueldad del régimen nacionalsocialista y los estragos causados por la II Guerra Mundial. Perdió familiares y amigos; al igual que millones de personas, fue recluida en un campo de internamiento; $y$, debido a su condición de judía, se vio obligada a huir de su Alemania natal para refugiarse, junto a su marido Heinrich Blücher, en Estados Unidos. La suerte quiso que, en lugar de perecer, se convirtiera "solo" en lo que ella calificaría como una paria, una refugiada apátrida sin hogar ni derechos. Su vivencia personal le empujó a ser una de las pioneras a la hora de abordar el mal acaecido en el siglo xx y sus manifestaciones, a intentar comprender qué es lo que habia ocurrido y cómo habia podido suceder. Con la convicción de que el problema del mal sería el tema filosófico fundamental de nuestro siglo ${ }^{1}$, su primer análisis de la cuestión, recogido en Los orígenes del totalitarismo - 1951-, gozó en general de un buen recibimiento por parte del público; un éxito truncado una década más tarde por la controvertida publicación de Eichmann en Jerusalén - 1963-. El objetivo que nos proponemos a continuación es, precisamente, tratar de comprender la concepción que Hannah Arendt manejaba acerca del mal y la evolución de su pensamiento. Para ello, el recorrido que proyectamos será el siguiente: 1) exponer concisamente la reflexión de Kant acerca del mal y algunos de sus problemas; (2) a la luz de esta indagación, analizar el primer enfoque arendtiano sobre la cuestión del mal, correspondiente a su obra Los orígenes del totalitarismo; (3) atender al cambio realizado por Arendt en su "estudio sobre la banalidad del mal" de Eichmann en Jerusalén; (4) determinar si ambas perspectivas son conciliables entre sí o no.

\section{El radical Böse kantiano: "El fuste torcido de la humanidad":}

IMMANUEl KANT PLASMÓ SUS REFLEXIONES sobre el mal principalmente en La religión dentro de los límites de la mera razón, obra que constituye el corolario de su ética - ya desarrollada en obras anteriores como la Crítica de la Razón Práctica y la

${ }^{1}$ Arendt, H., Ensayos de comprensión 1930-1954, Madrid, Caparrós Editores, 2005, p. 409. 
Fundamentación para una metafísica de las costumbres- y cuyo propósito consistía en averiguar cuál era el principio contrario a la moralidad y dónde arraigaba. De acuerdo con su posición deontológica, Kant ya había rechazado cualquier ética eudemonista que tomase la consecución de la felicidad como sinónimo del bien²; para él la ley moral era por sí misma motivo impulsor suficiente en el juicio de la Razón, de manera que todo aquel que hiciera de ella su máxima, esto es, todo aquel que siguiese el imperativo categórico, habría de ser considerado moralmente bueno ${ }^{3}$. Para ello, la libertad del albedrío humano se convierte en un requerimiento esencial dentro de la ética kantiana, puesto que solo puede existir la moralidad cuando los seres humanos no se encuentran determinados por causas externas a ellos mismos, sino cuando pueden elegir libremente y se les puede imputar y hacer responsables de sus propios actos; en otras palabras, "la visión kantiana de la moral presupone que somos agentes dotados de la capacidad de elegir libremente si obedecemos o no lo que nos dicta la ley moral. La responsabilidad moral requiere esta capacidad" 4 . De este modo, la bondad o maldad de una persona no vendría determinada propiamente por sus acciones, sino por las intenciones que tuviera a la hora de llevar a cabo la acción, es decir, de sus máximas morales y de sus principios impulsores: consideramos moralmente buena a una persona cuando esta tiene la ley moral como único motivo impulsor de su acción y obra sólo siguiendo la máxima por la cual quiere que al mismo tiempo se convierta en una ley universal; por el contrario, llamamos "malo a un hombre no porque ejecute acciones que son malas (contrarias a la ley), sino porque estas son tales que dejan concluir máximas malas en él" ${ }^{5}$. Los seres humanos no son, por lo tanto, buenos o malos por naturaleza, sino que llegan a ser lo uno o lo otro dependiendo de sus elecciones libres y de cómo incorporen la ley moral a sus máximas de acción. Ahora bien, lo que sí afirma Kant es que en la naturaleza humana existe una "Anlage zum Guten", una "predisposición al bien" — sobre la cual pueden injertarse diversos vicios, como los bestiales, los de la cultura o los diabólicos_ y una "Hang zum Bösen", una "propensión al mal" que se divide en tres grupos o niveles diferentes ${ }^{6}$ : (1) la fragilitas, la debilidad a la hora de resistir

\footnotetext{
2 "En qué cifre cada cual su felicidad depende de su particular sentimiento de placer y displacer, e incluso en uno y el mismo sujeto dependerá de la diferente menesterosidad marcada por la variación de tal sentimiento, de suerte que una ley subjetivamente necesaria (en cuanto ley natural) supone objetivamente un principio práctico harto contingente, que en distintos sujetos puede y ha de ser muy diferente, razón por la cual nunca es capaz de suministrar una ley" (Kant, I., Crítica de la razón práctica, Madrid, Alianza, 2011, p. 88; el destacado es del propio Kant).

3 Kant, I., La religión dentro de los límites de la mera Razón, Madrid, Alianza, 2009, p. 41.

${ }^{4}$ Bernstein, R., El mal radical, Buenos Aires, Prometeo Libros, 2012, p. 34.

Ibid., p. 36

${ }^{6}$ Como ha apuntado Richard Bernstein, Kant no distingue distintos grados cualitativos de "capacidad para el mal”, sino que los tres tipos de males (fragilitas, impuritas y perversitas) están relacionados con el fracaso del individuo a la hora de adoptar máximas buenas (BERNSTEIn, R., El mal radical, op. cit., p. 56).
} 
las tentaciones y para seguir los principios adoptados; (2) la impuritas, la mezcla de motivos impulsores morales con otros inmorales, de modo que a veces obramos por motivos ajenos al imperativo categórico; (3) y la perversitas, calificada como perversidad, malignidad y corrupción del corazón humano y que consistiría en "la propensión del albedrío a máximas que posponen el motivo impulsor constituido por la ley moral a otros (no morales)" "7, es decir, en anteponer otras máximas de acción a la ley moral. Este último modo de pensar está, en palabras del autor, "corrompido en su raíz" ${ }^{8}$ y es a partir de esto por lo que Kant puede empezar a hablar de un mal radical — radikal Böse-. Con el adjetivo "radikal" no pretende aludir a un tipo especial de mal o de máxima maligna, sino señalar que la propensión natural al mal de los hombres hunde sus raíces en la misma naturaleza humana y que su fundamento no puede ser puesto ni en nuestras inclinaciones naturales, ni en nuestra naturaleza sensible y fenoménica, ni tampoco en un defecto o corrupción intrínseca a la Razón moralmente legisladora ${ }^{9}$. El origen de este mal radical, que corrompe el fundamento de todas las máximas y no puede eliminarse a través de fuerzas humanas, se encuentra ligado entonces a una corrupción de la voluntad, a la propensión de la Willkür a desentenderse de la pureza de la intención y de los imperativos morales que emanan de la Razón en favor de otros que no son morales, de manera que la persona "invierte el orden moral de los motivos al acogerlos en su máxima" ${ }^{10}$; dicho en otras palabras, el mal radical pervierte la voluntad de manera que los hombres subordinan el seguimiento de la ley moral a otros motivos no morales ${ }^{11}$. Además, un problema adicional que conlleva esta perversidad del cora-

\footnotetext{
7 Kant, I., La religión dentro de los limites de la mera Razón, op. cit., p. 48.

8 Idem.

9 Es lo que Kant denomina, siguiendo a las grandes religiones, el "fuste torcido de la humanidad": "A partir de una madera tan retorcida como de la que está hecho el hombre no puede tallarse nada enteramente recto" (KANT, I., "Ideas para una historia universal en clave cosmopolita", en Ideas para una historia universal en clave cosmopolita y otros escritos sobre Filosofía de la Historia, Madrid, Tecnos, 2010, p. 12; el destacado es mío).

${ }_{10}$ Kant, I., La religión dentro de los límites de la mera Razón, op. cit., p. 56.

11 Ver también el análisis del mal radical realizado por Karl Jaspers en "El mal radical según Kant" (Conferencias y ensayos sobre historia de la filosofía, Madrid, Gredos, 1972, pp. 141-164): "Una voluntad es propiamente mala cuando hace el cumplimiento del deber, es decir, la conducta según la ley, dependiente de la satisfacción de las tendencias instintivas naturales y de la satisfacción de sus exigencias de felicidad. Aquí se da entonces una inversión (o perversión) de la relación de subordinación. Se llama mala, porque esa voluntad ha hecho de esta inversión un principio secreto o manifiesto de conducta. Es posible que realice obras legalmente buenas, pero se deberá a la feliz casualidad de que en ese momento no haya una colisión entre el cumplimiento de la ley y la satisfacción de su tendencia a la felicidad. Es mala, además, porque en su estructura mental ha admitido aquella inversión de condicionamiento para el caso de conflicto. [...] Tal voluntad se llama también radicalmente mala, porque se ha corrompido en ella la fuente de los principios. No se trata entonces de una voluntad aislada, que es mala y que, como tal, podría de alguna forma convertirse en buena, ya que la raíz de la misma seguía estando sana; sino que es una voluntad con toda propiedad radicalmente mala, de la que sólo puede proceder mala conducta, aunque su obrar, en un momento concreto, sea una acción objetivamente buena. A esta perversión de la relación de condicionamiento la llama Kant la propensión al mal” (pp. 144-145).
} 
zón humano es la tranquilidad de conciencia que aporta a aquel que comete malas acciones como consecuencia del desistimiento del juicio moral, pues la radicalidad del mal conlleva también un "engañarse a sí mismo acerca de las intenciones propias buenas o malas y [...] no inquietarse por la intención propia, sino más bien tenerse por justificado ante la ley" ${ }^{12}$. Esto es lo que permite a los hombres no sentirse culpables por sus faltas y delitos, despertando la indignación de Kant:

Esta deshonestidad consistente en mostrarse fantasmagorías, que impiden el establecimiento de una genuina intención moral en nosotros, se amplía al exterior en falsedad y engaño de otros; lo cual, si no debe ser llamado maldad, merece al menos llamarse indignidad, y reside en el mal de la naturaleza humana, el cual [...] constituye la mancha pútrida de nuestra especie, mancha que, en tanto no la apartamos, impide que el germen del bien se desarrolle ${ }^{13}$.

Ahora bien, esta posición pondría también un límite al alcance del mal dentro de la teoría kantiana, pues a ojos del autor de La Religión dentro de los límites de la mera Razón sería imposible la existencia de personas "diabólicas", es decir, de individuos poseedores de una Razón maliciosa o una voluntad absolutamente mala cuyo único motivo impulsor para la acción fuese el enfrentamiento u oposición a la ley moral misma; esto es, que actuasen movidos única y exclusivamente por la intención de hacer el mal en el sentido de transgredir sistemáticamente las leyes morales. Si el mal radical supone engañarse a uno mismo respecto a las intenciones, entonces nadie podría realizar el mal a sabiendas de que con sus actos está quebrantando las leyes morales dictadas por la Razón.

En cualquier caso, dado que para Kant el mal está radicalmente inscrito en el hombre, como propensión de su naturaleza, resulta inextirpable y nos es imposible hallar su causa última, de modo que nunca podremos estar plenamente seguros de estarnos comportando de una forma moralmente buena y de no estar superponiendo nada a la ley moral. Tan solo podemos esforzarnos por tratar de prevalecer sobre esta inclinación, lo cual debe ser posible para el hombre debido a su libertad como agente moral y al germen del bien que se halla en el corazón de todos nosotros ${ }^{14}$.

Sin embargo, la teoría kantiana acerca del mal también posee una serie de problemas o incoherencias no resueltas por el autor ${ }^{15}$. En primer lugar, quedaría la duda de por qué no pueden existir seres diabólicos, puesto que si la Willkür o voluntad del hombre es libre, entonces les debería ser posible a las personas oponerse libre-

12 Kant, I., La religión dentro de los limites de la mera Razón, op. cit., p. 58.

3 Idem.

${ }^{14}$ Ibid., pp. 66-67.

15 Para el siguiente análisis me apoyo fundamentalmente en la crítica de Bernstein (El mal radical, op. cit.). 
mente a la ley moral, rechazándola sistemática y deliberadamente; sin embargo, Kant se cierra a esta posibilidad sin dar ninguna explicación al respecto. En segundo lugar, cuando Kant caracteriza al hombre malvado como aquel que superpone otras motivaciones a la ley moral, suele poner el "amor a sí mismo" como ejemplo de ello; sin embargo, como resalta Bernstein, si una persona tuviera la empatía hacia los demás como incentivo primario de su acción, a ojos del pensador del Königsberg habríamos de situar a este individuo en la misma categoría de malignidad que el primero, lo que no solo resulta contraintuitivo o una consecuencia negativa del rigorismo kantiano, sino incluso una perversidad. En tercer lugar, la tesis de que la propensión al mal moral es universal y se encuentra enraizada en la naturaleza humana, resulta incompatible con el hecho de que el hombre sea responsable de ella — dos sentencias afirmadas simultáneamente por Kant—, pues ¡cómo puede ser alguien responsable por algo que se encuentra arraigado en la propia humanidad? Nuevamente el filósofo prusiano nos deja sin respuesta. En cuarto lugar, Kant nunca llega a descubrir la causa acerca de por qué el mal ha corrompido nuestras máximas; tan solo dice que la propensión es resultado del ejercicio de nuestra libertad, lo que difícilmente se conjuga con su afirmación de que dicha inclinación al mal es también innata y congénita. Finalmente, Kant también expone que el mal es radical porque es inextirpable del ser humano y corrompe el fundamento de todas sus máximas, de manera que la Willkür se encontraría corrompida de raíz; sin embargo, posteriormente añade que deber ser posible para el hombre superar este mal a través del libre ejercicio de la Willkür, lo que nos sitúa ante una paradoja: ¿cómo puede la Willkür ayudarnos a superar la propensión al mal cuando esta se encuentra ya corrompida de raíz? En todo caso, sería imposible que este mal corrompiese el fundamento de todas nuestras máximas puesto que, de ser así, no existiría ninguna posibilidad de adoptar una máxima moralmente buena y, en consecuencia, ninguna posibilidad de superar el mal radical. Como mantiene Bernstein, todas estas dificultades se deberían al hecho de que Kant está combatiendo contra sí mismo:

Por un lado, no quiere comprometer la idea básica de su filosofía moral: que los seres humanos en tanto agentes finitos y racionales son libres, lo cual implica que son pura y totalmente responsables de sus elecciones morales y de las máximas de acción que adoptan. $\mathrm{Si}$ nos volvemos moralmente buenos o malos es asunto nuestro, y una consecuencia de nuestra voluntad libre (Willkür). Por otro lado, Kant también quiere sostener que todos los seres humanos tienen una innata propensión al mal moral. A fines de hornear el pastel y comérselo, llega al extremo de afirmar que aun cuando esta propensión está entrelazada en el tejido de la naturaleza humana, es una propensión que surge de nuestra libertad, y de la que somos responsables ${ }^{16}$.

${ }_{16}$ Bernstein, R., El mal radical, op. cit., p. 62. 


\section{Arendt: "mal radical" o"mal absoluto"}

Por otra parte, cuando Hannah Arendt emplea el término "mal radical" insiste en que el significado que le da se aleja tanto del proporcionado por la teología cristiana como del que le había conferido el filósofo prusiano, quien habría dado origen al término, pero al que también acusa de haberlo pretendido racionalizar:

Es inherente a toda nuestra tradición filosófica el que no podamos concebir un "mal radical", y ello es cierto tanto para la teología cristiana, que concibió incluso para el mismo Demonio un origen celestial, como para Kant, el único filósofo que, en el término que acuño para este fin, debió de haber sospechado al menos la existencia de este mal, aunque inmediatamente lo racionalizó a través del concepto de "mala voluntad pervertida", que podía ser explicada por motivos comprensibles ${ }^{17}$.

Para Arendt, Kant no aludía a lo mismo que ella cuando empleó la expresión "mal radical", pues mientras el autor de La Religión dentro de los límites de la mera Razón la remitía a la propensión de la libre voluntad de desentenderse de los imperativos morales emanados de la Razón, Arendt considera que este mal no puede concebirse en modo alguno, premisa que rechazaría el filósofo de Königsberg. Para la pensadora, como veremos más adelante, el mal radical se caracterizará por ser incomprensible y por hacer superfluos a los seres humanos.

En Los orígenes del totalitarismo, la obra cumbre en la que comienza a abordar el tema del mal, y concretamente en el apartado de la "Dominación total", Arendt describe este "mal radical" o "mal absoluto" —expresiones que emplea como sinónimas - como un mal desconocido hasta el momento, sin paralelo alguno en la historia, y que apareció en las fases finales del totalitarismo. Se trata de un fenómeno completamente nuevo, sin precedentes, que "nos enfrenta con su abrumadora realidad y destruye todas las normas que conocemos" ${ }^{18}$, ante el cual la tradición filosófica occidental carecía de las categorías y del aparato conceptual necesario para abordarlo de un modo teórico: "dicho mal absoluto sólo podía ser iluminado por medio de un análisis de los «elementos» que cristalizan en el totalitarismo, tales como la explosión demográfica, la expansión y superfluidad económicas, el desarraigo social y el deterioro de la vida política" ${ }^{19}$. Se trata de una manifestación del mal que, por una parte, no se ajusta a las nociones tradicionales que teníamos de él - que explicaban sus formas extremas como perversiones de los sentimientos humanos-, y por otra, responde a objetivos inéditos que se resumen en la destruc-

\footnotetext{
${ }_{17}$ Arendt, H., Los orígenes del totalitarismo, Madrid, Alianza, 2010., pp. 615-616.

18 Ibid., p. 616.

19 Young-Bruehl, E., Hannah Arendt. Una biografía, Barcelona, Paidós, 2006, p. 279.
} 
ción de la idea de humanidad ${ }^{20}$. Un mal cuyo origen cronológico —en el nazismo- Arendt sitúa alrededor de 1934, tras la Nacht der langen Messer ("Noche de los cuchillos largos") ${ }^{21}$, año a partir del cual el terror nazi dejaría de estar en manos de las SA, guiadas por una ciega bestialidad y por profundos sentimientos de odio y resentimiento, para pasar al control de las SS, quienes llevarían a cabo la Shoah y operarían de una manera fría, sistemática y calculada.

Según el análisis de Arendt, este mal absoluto o radical se caracteriza por tres rasgos fundamentales: es incomprensible, incastigable e imperdonable. "Incomprensible" porque no puede ser deducido o explicado a la luz de las motivaciones malvadas clásicas, pasiones perversas o causas pecaminosas humanamente inteligibles, como el egoísmo, el poder, la cobardía, el interés propio, etc. "Incastigable" porque sus crímenes "no están contemplados en los Diez Mandamientos" 22, así como las prohibiciones morales tradicionales no son adecuadas para condenarlos y van más allá de lo previsto y legislado por cualquier categoría jurídica. E "imperdonable" porque trasciende la esfera de los asuntos humanos y porque, como expone en $\mathrm{La}$ condición humana, ningún ser humano es capaz de perdonar aquello que no puede castigar $^{23}$. Es un mal que, "hablando estrictamente, no es castigable ni perdonable, porque el castigo y el perdón presuponen aquello que el mal radical intenta erradicar, es decir, la acción humana" ${ }^{24}$. Dicho con palabras de la propia Arendt:

En su esfuerzo por demostrar que todo es posible, los regímenes totalitarios han descubierto sin saberlo que hay crímenes que los hombres no pueden castigar ni perdonar. Cuando lo imposible es hecho posible se torna en un mal absolutamente incastigable e imperdonable que ya no puede ser comprendido ni explicado por los motivos malignos del interés propio, la sordidez, el resentimiento, el ansia de poder y la cobardía. Por eso la ira no puede vengar; el amor no puede soportar; la amistad no puede perdonar. De la misma manera que las víctimas de las fábricas de la muerte o de los pozos del olvido ya no son "humanos" a los ojos de sus ejecutores, así estas novísimas especies de criminales quedan incluso más allá del umbral de la solidaridad de la iniquidad humana ${ }^{25}$.

${ }^{20}$ Marrades, J., "La radicalidad del mal banal", en Logos. Anales del Seminario de Metafísica, Vol. 35, 2002, p. 85.

${ }^{21} \mathrm{La}$ "Noche de los cuchillos largos", en la que tuvo lugar la detención de Ernst Röhm y la purga de las SA —con más de 400 asesinatos - tuvo lugar la noche del 30 de julio de 1934. Röhm sería asesinado al día siguiente.

22 Arendt, H. \& Jaspers, K., Correspondence 1926-1969 (Kohler, L. \& Saner H eds.), Orlando, Harcourt Brace Jovanovich, 1992, p. 166.

23 "Es muy significativo, elemento estructural en la esfera de los asuntos públicos, que los hombres sean incapaces de perdonar lo que no pueden castigar e incapaces de castigar lo que ha resultado ser imperdonable. Esta es la verdadera marca de contraste de esas ofensas que, desde Kant, llamamos "mal radical" y sobre cuya naturaleza se sabe tan poco. Lo único que sabemos es que no podemos castigar ni perdonar dichas ofensas, que, por consiguiente, trascienden la esfera de los asuntos humanos y las potencialidades del poder humano" (ArENDT, H., La condición humana, Barcelona, Paidós, 2015, p. 260).

24 Bernstein, R., “¿Cambió Hannah Arendt de opinión? Del mal radical a la banalidad del mal”, en Birulés, F. (Comp.), Hannah Arendt: el orgullo de pensar, Barcelona, Gedisa, 2009, pp. 250-251.

25 Arendt, H., Los orígenes del totalitarismo, op. cit., p. 615. 
Sin embargo, esto no quiere decir que la pensadora alemana entendiera los crímenes del nacionalsocialismo como unos actos perpetrados por monstruos o demonios; todo lo contrario. Para Arendt, la "grandeza satánica" que muchos atribuyeron al III Reich no era un elemento relevante, ni mucho menos útil, para entender la dominación y la ignominia nazi, sino que rechazaba cualquier intento de mitificar, moral o estéticamente, el horror del régimen de Adolf Hitler y las intenciones de sus responsables; para ella, el mal radical no tenía nada que ver con una dimensión mefistofélica. Es verdad que, según su juicio, este mal no podía ser comprendido a partir de los motivos clásicos ofrecidos por la historia y la literatura, pero los crímenes a los que dio lugar fueron cometidos por seres humanos, personas de carne y hueso que se veían como el instrumento de un programa de purificación de la raza, donde la deportación, la tortura y el asesinato no eran más que simples métodos y técnicas de gestión de la llamada Solución Final.

El mal radical se encuentra estrechamente vinculado a la dominación totalitaria pretendida por el nacionalsocialismo, en la que los campos de concentración se convierten en su institución central y más representativa. Esta dominación total, "que aspira a organizar la pluralidad y diferenciación infinitas de los seres humanos como si la humanidad fuese justamente un individuo, sólo es posible si todas y cada una de las personas pudieran ser reducidas a una identidad nunca cambiante de reacciones, de forma tal que pudieran intercambiarse al azar cada uno de estos haces de reacciones" ${ }^{26}$. Este objetivo era el que se pretendía conseguir en los Lager a través de la destrucción de la espontaneidad e impredecibilidad humanas — que Arendt asocia a su noción de "natalidad" ${ }^{27}$, de la pluralidad de sus víctimas y del carácter individual de cada persona particular. En otras palabras, se buscaba hacer "superfluos" a los hombres, transformarlos de tal manera que ya no fueran seres humanos, sino marionetas incapaces de pensar o actuar por sí mismos y desarraigadas del mundo. Para ello, los nazis trataron de llevar a cabo una triple destrucción de la persona: desde el punto de vista jurídico — suprimir sus derechos y protecciones legales, mezclar inocentes con presos, reducir al individuo a una vestimenta, un número o una insignia...- - desde el punto de vista moral — ponerla ante situaciones donde las fronteras entre el bien y el mal se difuminan, convirtiendo a las propias víctimas en perpetradores de los crímenes-y finalmente eliminando su individualidad — acabar con su capacidad para iniciar cualquier curso de acción por sí mis$\mathrm{ma}$, anular las diferencias individuales, dañar a los prisioneros física y mentalmente, minar su dignidad como seres humanos, quebrar su voluntad- - . El resultado de

\footnotetext{
${ }^{26}$ Ibid., p. 589.

27 Arendt, H., La condición humana, op. cit.
} 
este proceso fue la fabricación de "cadáveres vivientes", de los Muselmänner descritos por Primo Levi, seres demacrados, de cabeza gacha, espalda encorvada y mirada vacía, a los que los propios prisioneros no sabían si calificar como vivos o muertos ${ }^{28}$ y que reflejaban el intento de los nazis de destruir la idea misma de humanidad para redefinirla según sus criterios. A través de este infierno en la Tierra creado por el hombre, no solo se consigue el exterminio de las víctimas, sino que además "previamente se procura la supresión de la persona y de su carácter de ser humano, y posteriormente se borra todo rastro o recuerdo de su existencia misma. Por ello, el mal [radical] trasciende la muerte y procura la desaparición de las víctimas del mundo, negándoles, de este modo, la disposición de su propia muerte como cierre del trayecto de una existencia" 29 .

\section{La "banalidad del mal"}

Sin embargo, CON el paso Del tiempo este análisis terminó por resultar insuficiente a ojos de la autora, para quien la "necesidad de comprender" resultaba algo esencial ${ }^{30}$. Arendt concebía la comprensión, no como una negación de la realidad o de lo que nos resulta deshonroso y vergonzoso, ni tampoco como una aceptación sumisa de los hechos; para ella comprender significaba "examinar y soportar conscientemente la carga que nuestro siglo ha colocado sobre nosotros [...] un atento e impremeditado enfrentamiento con la realidad, una resistencia a la misma, sea lo que fuere" ${ }^{31}$. Esta necesidad fue la que le empujó a seguir indagando acerca de la cuestión del mal, que desembocó en la conocida formulación de la "banalidad del mal". Después del planteamiento realizado en Los orígenes del totalitarismo acerca del mal radical, que en general había tenido una buena acogida, la nueva posición adoptada por Arendt a raíz del juicio del teniente coronel de las SS Adolf Eichmann suscitó una enorme controversia, tanto en el seno de la comunidad judía - acusándola de traidora - como en el ámbito intelectual —abriendo el debate acerca de si había cambiado su parecer o si, por el contrario, existía una continuidad en su pensamiento-.

Por otra parte, existían ya una serie de esbozos acerca de la idea de "banalidad del mal" antes de que Arendt la sacase a la luz en 1963. Para empezar, en su ensa-

\footnotetext{
${ }_{28}$ Levi, P., Trilogía de Auschwitz, Barcelona, El Aleph, 2012, pp. 120-121.

29 Di Pego, A., "Las concepciones del mal en la obra de Hannah Arendt. Crítica de la modernidad y retorno a la filosofía", en Revista Al Margen, no 21 y 22, 2007, p. 91.

30 Arendt, H., Lo que quiero es comprender, Madrid, Trotta, 2010, p. 44.

31 Arendt, H., Los orígenes del totalitarismo, op. cit., p. 26.
} 
yo de 1945 "Culpa organizada y responsabilidad universal" ya había señalado un elemento crucial en el que, desafortunadamente, no reparó lo suficiente hasta muchos años más tarde: "la organización omniabarcante de Himmler no descansa en fanáticos ni en asesinos natos ni en sádicos; descansa por entero sobre la normalidad de los empleados y los cabezas de familia" 32 . En este escrito Arendt ya apuntaba cómo personas normales, padres de familia tan solo preocupados por el bienestar de los suyos, fueron las que dieron pie al Holocausto y cómo estuvieron dispuestos a hacer todo lo que fuera necesario para librar a sus familias de cualquier amenaza a cambio de una completa exención de responsabilidad. Por otro lado, en 1946, en su correspondencia con Karl Jaspers acerca de la obra de este último Die Schuldfrage ${ }^{33}$, el filósofo alemán le llegó a escribir:

[...] Una culpa que trascienda toda culpa criminal inevitablemente tiene una veta de "grandeza", de grandeza satánica, que es para mí tan inapropiada como toda la charla sobre el elemento "demoníaco" en Hitler y esas cosas. Me parece que tenemos que entender esos fenómenos en su total banalidad, en su trivialidad prosaica, porque eso es lo que los caracteriza realmente ${ }^{34}$.

En todo caso, el juicio de Eichmann en Jerusalén y la oportunidad de verlo cara a cara supuso para Arendt lo que ella calificó como una "cura posterior" ${ }^{35}$. Al igual que el resto de personas, la que fuera enviada como reportera del The New Yorker esperaba contemplar a un ser monstruoso, sádico y cruel, cuya expresión transmitiese a los demás que era él quien había estado tras el asesinato de más de cinco millones de judíos. Sin embargo, el hombre que encontró tras la cabina de cristal resultó ser, a su parecer, una persona completamente diferente, alguien absolutamente normal, como certificaron varios psicólogos y su confesor, e incluso llegará a calificarlo como un "payaso" ${ }^{36}$. En ese momento, Arendt se dio cuenta de que había sobrevalorado en algunos aspectos el papel de la ideología y que se hallaba frente a un nuevo tipo de criminal, un hostis humani generis ${ }^{37}$ resultado de los fenómenos burocráticos y tecnológicos propios de la modernidad. A lo largo del proceso, pudo atestiguar cómo Eichmann era una persona que, sencillamente, no se percató nunca de lo que hacía; no en el sentido de que no supiera que estaba mandando a

\footnotetext{
32 Arendt, H., Ensayos de comprensión 1930-1954, op. cit., p. 162; el destacado es mío.

33 El problema de la culpa, en su traducción al castellano: JAspers, K., El problema de la culpa, Barcelona, Paidós, 1998.

34 Bernstein, R., “¿Cambió Hannah Arendt de opinión? Del mal radical a la banalidad del mal”, op. cit., p. 249 (original en Arendt, H. \& Jaspers, K., Correspondence 1926-1969, op. cit., p. 62); el destacado es mío.

35 Young-Bruehl, E., Hannah Arendt. Una biografía, op. cit., p. 414.

36 Arendt, H., Eichmann en Jerusalén, Barcelona, DeBolsillo, 2011, p. 85.

37 Ibid., p. 403.
} 
millones de personas a una muerte segura, sino en el de que nunca obró movido por motivaciones malignas. El que fuera encargado de la antigua Subsección IV-B-4 de la RSHA era simplemente un individuo que se había vuelto incapaz de distinguir el bien del mal; para él, siguiendo lo que Weber denominaría "honor del funcionario" 38 , el "bien" era cumplir su cometido de la manera más eficaz que pudiera. Eichmann era totalmente incapaz de pensar o juzgar cualquier acción por sí mismo, había interiorizado su trabajo como un mero hábito o rutina y la voz de su conciencia había sido sustituida por la voz del Führer, a quien, en consecuencia, prestaba una obediencia completamente ciega. El imperativo categórico kantiano, que en el juicio afirmaba haber seguido, se había transmutado en realidad en el imperativo categórico del III Reich — obra de tal manera que si el Führer te viese aprobase tus actos-; y aunque nunca asesinó a nadie con sus propias manos, confesó que habría matado a su propio padre si se lo hubieran ordenado. Dicho con otras palabras, Arendt se sorprendió de la carencia que tenía Eichmann de ese diálogo interno y silencioso que mantiene uno consigo mismo y que constituye el pensamiento, el cual permite la facultad de juzgar, de distinguir el bien del mal y, por ende, de evitar catástrofes ${ }^{39}$. Aun así, el antiguo SS no era un engranaje más dentro de la maquinaria de exterminio nazi, sino que, pese a que las condiciones burocráticas y tecnológicas posibilitasen su trabajo de una manera más eficiente y sin ningún cargo de conciencia, Eichmann seguía siendo también culpable y responsable de sus actos. En palabras de Arendt:

Si la capacidad de distinguir lo bueno de lo malo debe tener algo que ver con la capacidad de pensar, entonces debemos poder "exigir" su ejercicio a cualquier persona que esté en su sano juicio, con independencia del grado de erudición o de ignorancia, inteligencia o estupidez que pudiera tener ${ }^{40}$.

Y Eichmann, sin ninguna duda, era alguien lo suficientemente normal como para exigirle dicho ejercicio.

En todo caso, el problema no residía en el propio Eichmann en sí, sino que la auténtica gravedad del asunto era que "hubo muchos hombres como él, y que estos hombres no fueron pervertidos y sádicos, sino que fueron, y siguen siendo, terrible y terrorificamente normales" ${ }^{\prime 1}$. La banalidad del mal no involucraba así a sectores mi-

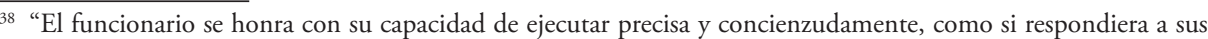
propias convicciones, una orden de la autoridad superior que a él le parece falsa, pero en la cual, pese a sus observaciones, insiste la autoridad, sobre la que el funcionario descarga, naturalmente, toda la responsabilidad" (Weber, M., El politico y el científico, Madrid, Alianza, 2004, pp. 115-116).

39 Arendt, H., Responsabilidad y juicio, Barcelona, Paidós, 2015, pp. 161-184.

40 Ibid., p. 165.

${ }^{41}$ Arendt, H., Eichmann en Jerusalén, op. cit., p. 402; el destacado es mío.
} 
noritarios, fanáticos e ideologizados, sino que se extendía a los ciudadanos corrientes, anónimos, que con su actividad o pasividad contribuyeron a la consolidación del III Reich y a la perpetración del Holocausto. De hecho, tal y como han revelado investigaciones posteriores, Eichmann queda muy lejos de ser un paradigma de la banalidad del mal, sino que existen otros casos resultan más adecuados para ejemplificarlo, como el del comandante de Treblinka Franz Stangl (entrevistado por la periodista Gitta Sereny), o aquellos hombres grises que componían el Batallón de Reserva Policial 101 (analizados por Christopher Browning) ${ }^{42}$. Lo verdaderamente preocupante, y que llamó poderosamente la atención de Arendt, es el "total colapso moral" que el nazismo había producido dentro de la sociedad, demostrando lo fácil que resultaba cambiar las costumbres, los hábitos y las reglas de la moral tradicional por sus opuestos ${ }^{43}$. El régimen de Hitler pudo imponerse y transformar las pautas sociales de comportamiento porque hasta entonces la gran mayoría de la población se había guiado por un seguimiento ciego de las normas establecidas, sin prestar atención a su contenido; "carentes de un pensamiento independiente en asuntos morales y políticos, esas personas pudieron adoptar el nuevo sistema sin mayores conflictos, pues con ello no hacían más que seguir refugiándose en las normas aceptadas" ${ }^{44}$. En esta medida, como expone la autora de Eichmann en Jerusalén, el mal perdió su característica distintiva de ser una tentación ${ }^{45}$, haciéndose indetectable e infiltrándose por todos los resquicios de la actitud moral del pueblo alemán.

La esencia de la banalidad del mal consiste entonces en que no son necesarias malas motivaciones o intenciones para realizar malas acciones; disposiciones normales o triviales, como la ambición en el trabajo, la pretensión de reconocimiento social o inclu-

\footnotetext{
42 Sereny, G., Desde aquella oscuridad, Barcelona, Edhasa, 2009; Browning, C.R., Aquellos hombres grises, Barcelona, Edhasa, 2002. En el artículo "Modalidades del mal durante el nacionalsocialismo" (en Quaderns de filosofia, Vol. v, no I, 2018, pp. 11-28; pp. 14-15) enumero someramente algunas de estas razones por las que Arendt debería haber prescindido de Eichmann como imagen y modelo de la banalidad del mal. Sin embargo, quizá el mejor estudio a este respecto se encuentra en la obra de Bettina Stangneth Eichmann before Jerusalem (London, The Bodley Head, 2014), en la que la filósofa e historiadora alemana desmonta el retrato realizado por Arendt para desvelar al verdadero Adolf Eichmann: un fanático y convencido nacionalsocialista que hizo mucho más que "obedecer órdenes". Esto no significa que la propuesta de Arendt quede invalidada; tan solo que no se aplica al caso que le inspiró. Por este motivo, conviene distinguir también el "Eichmann histórico" o "Eichmann real" de lo que yo denomino el "modelo Eichmann", es decir, el perfil descrito por Arendt y que puede ser aplicado a multitud de individuos. En este sentido, el caso de Franz Stangl resultaría más adecuado para representar la "banalidad del mal" en la medida en que no fue nunca un fanático, sino una persona "normal", nunca desobedeció una orden — ningún superviviente del campo o subordinado suyo contradice este hecho- - su entrevista fue realizada con el conocimiento de que no sería utilizada para la revisión de su caso. Por su parte, Christopher Browning recoge el caso del Batallón de Reserva Policial 101, compuesto por ciudadanos alemanes comunes que no estaban imbuidos de la ideología nacionalsocialista, pero que entre marzo de 1942 y noviembre de 1943 se convirtieron en una pieza clave en el exterminio nazi realizado en el frente oriental, concretamente en Polonia.

43 Bernstein, R., El mal radical, op. cit., p. 342.

${ }^{44}$ Marrades, J., "La radicalidad del mal banal", op. cit., p. 90.

45 Arendt, H., Eichmann en Jerusalén, op. cit., p. 219.
} 
so el propósito de disfrutar de una vida tranquila junto a la familia, bastan para llegar a causar las mayores atrocidades. Con esto, Arendt cuestiona una de las convicciones filosóficas, teológicas y legales más arraigadas en la larga tradición de Occidente, a saber, que las malas acciones presuponen malas intenciones y motivaciones por parte de quienes las realizan. Su planteamiento supone un desafío a la equivalencia entre el grado de malicia de los actos y la maldad de los motivos o de la intención, así como pone en tela de juicio que las personas que cometen dichas acciones hayan de ser necesariamente sádicas, perversas, demoníacas o, en resumen, malignas. Lo que caracteriza la banalidad del mal es la carencia de toda capacidad crítica y autónoma para analizar la realidad, poner en cuestión las normas y criterios establecidos y discernir el bien del mal, así como de lo que, partiendo de Kant, Arendt denomina una "mentalidad ampliada", esto es, la capacidad del individuo de ponerse en el lugar de los otros y de formar su propio juicio teniendo en cuenta los de los demás ${ }^{46}$. En síntesis, es la total ausencia de pensamiento y de la facultad de juzgar por uno mismo. Para la autora, "una de las lecciones que nos dio el proceso de Jerusalén fue que tal alejamiento de la realidad y tal irreflexión pueden causar más daño que todos los malos instintos inherentes, quizá, a la naturaleza humana” ${ }^{47}$.

Ahora bien, también debe aclararse que cuando Arendt acunó el término no estaba pensando en establecer ningún tipo de teoría; su única pretensión era referirse a un fenómeno que, bajo su punto de vista, había quedado patente a lo largo del proceso:

Hace algunos años, en mi reportaje sobre el proceso de Eichmann en Jerusalén, hablé de la "banalidad del mal", y con esta expresión no aludía a una teoría o una doctrina, sino a algo absolutamente fáctico, al fenómeno de los actos criminales, cometidos a gran escala, que no podían ser imputados a ninguna particularidad de maldad, patología o convicción ideológica de la gente, cuya única nota distintiva personal era quizás una extraordinaria superficialidad. Sin embargo, a pesar de lo monstruoso de los actos, el agente no era un

\footnotetext{
${ }^{46}$ En la Crítica del Juicio, Kant habla acerca de esta "mentalidad ampliada" pero aplicándola al gusto y al juicio estético. En concreto, define el amplio modo de pensar como una máxima del entendimiento común humano que se da cuando un hombre "puede apartarse de las condiciones privadas subjetivas del juicio, dentro de las cuales tantos otros están como encerrados, y reflexiona sobre su propio juicio desde un punto de vista universal' (Kant, I., Crítica del Juicio. Madrid. Tecnos, 2007, pp. 219-220). Según Arendt, Kant no habría reconocido las implicaciones políticas y morales de su descubrimiento, de manera que es ella quien decide exponerlas: "El pensamiento político es representativo; me formo una opinión tras considerar determinado tema desde diversos puntos de vista, recordando los criterios de los que están ausentes; es decir, los represento. [...] Cuantos más puntos de vista diversos tenga yo presentes cuando estoy valorando determinado asunto, y cuanto mejor pueda imaginarme cómo sentiría y pensaría si estuviera en lugar de otros, tanto más fuerte será mi capacidad de pensamiento representativo y más válidas mi conclusiones, mi opinión. [...] El proceso mismo de formación de la opinión está determinado por aquellos en cuyo lugar alguien piensa usando su propia mente, y la única condición para aplicar la imaginación de este modo es el desinterés, el hecho de estar libre de los propios intereses privados" (AREndt, H., Entre el pasado y el futuro, Barcelona, Península, 1996, p. 254).

47 Arendt, H., Eichmann en Jerusalén, op. cit., p. 418.
} 
monstruo ni un demonio, y la única característica específica que se podía detectar en su pasado, así como en su conducta a lo largo del juicio y del examen policial previo fue algo enteramente negativo: no era estupidez, sino una curiosa y absolutamente auténtica incapacidad para pensar ${ }^{48}$.

Por este motivo, la expresión "banalidad del mal" resulta controvertida y provocadora, porque supone que no podemos seguir confiando en las categorías, conceptos y normas morales tradicionales para comprender el mal acaecido en el siglo xx; por el contrario, nos insta a pararnos a pensar y enfrentar las nuevas formas que el mal ha adoptado en nuestro tiempo:

La tarea es forjar nuevos conceptos y categorías que iluminen la oscuridad de nuestro tiempo. Debemos aprender a apartarnos de las dicotomías simplificadoras en las que se asume falsamente que si negamos que alguien tenga intenciones malas deliberadas, estamos afirmando su inocencia. Debemos aprender a comprender cómo alguien puede no tener malas intenciones y ser "aterradoramente normal", y al mismo tiempo ser responsable y punible por sus actos ${ }^{49}$.

Curiosamente, consenciente de la polémica que semejante planteamiento podría causar, la propia Arendt apenas empleó el término en Eichmann en Jerusalén ${ }^{50}$; sin embargo, su esfuerzo y su atrevimiento han sido con posterioridad sumamente elogiados y referenciados desde diversos ámbitos y por distintas figuras. Por ejemplo, dentro de la psicología social, en su estudio acerca de la obediencia a la autoridad y del comportamiento humano en situaciones extremas, Stanley Milgram afirmó:

Tras haber sido testigo de cómo cientos de personas corrientes se sometían a la autoridad en los experimentos que nosotros llevábamos a cabo, me es preciso concluir que la concepción de Arendt sobre la banalidad del mal se halla mucho más cerca de la verdad de lo que pudiera uno atreverse a imaginar. [...] Es posible que sea esta la lección más fundamental de nuestro estudio: las personas más corrientes, por el mero hecho de realizar las tareas que les son encomendadas, y sin hostilidad particular alguna por su parte, pueden convertirse en agentes de un proceso terriblemente destructivo ${ }^{51}$.

\footnotetext{
${ }_{48}$ Arendt, H., Responsabilidad y juicio, op. cit., p. 161; a este respecto, ver también: Arendt, H., La vida del espiritu. Barcelona, Paidós, 2015, pp. 29-31.

49 Bernstein, R., “¿Son todavía relevantes las reflexiones de Arendt sobre el mal?”, en Revista Al Margen, no 21 y 22, 2007, p. 58.

50 Arendt utilizó la expresión "banalidad del mal" tan solo dos veces en la obra: la primera, al final del último capítulo y la segunda, en el Post Scríptum — páginas 368 y 417 de nuestra edición—; también emplea la palabra "banalidad" una vez — pág. 418 - para referirse a la irreflexión de Eichmann. Incluso el subtítulo de la obra, "un estudio sobre la banalidad del mal", no estuvo presente en la aparición de los artículos originales publicados en The New Yorker.

51 Milgram, S., Obediencia a la autoridad, Bilbao, Desclée De Brouwer, 1980, p. 19.
} 
Y por su parte, en sus estudios sobre los factores situacionales, Philip Zimbardo diría:

La expresión de Arendt "la banalidad del mal" sigue resonando hoy en día porque el genocidio se ha desatado por todo el mundo y la tortura y el terrorismo siguen formando parte del panorama mundial. Preferimos distanciarnos de una verdad tan básica y ver la locura de los criminales y la violencia sin sentido de los tiranos como rasgos de su manera de ser personal. El análisis de Arendt fue el primero en negar esta orientación al observar la fluidez con la que las fuerzas sociales pueden hacer que personas normales cometan actos horrendos ${ }^{52}$.

Volviendo al pensamiento de Arendt, esta nueva concepción del mal supuso aparentemente un distanciamiento respecto a su anterior posición sobre la cuestión. A partir del juicio a Eichmann, que significó una suerte de cura posterior "de esa especie de implicación emocional que enturbia el buen juicio" 53, la filósofa varió su opinión acerca de la comprensibilidad de los motivos: no es que el mal engendrado por el totalitarismo fuese incomprensible, sino que las intenciones o disposiciones tradicionales no eran adecuadas para dar cuenta de él; había que cambiar de óptica y analizar otro tipo de motivaciones, más comunes, más triviales, más banales, despojadas de cualquier tipo de grandeza y malignidad, no tenidas en cuenta hasta el momento. Aquellas "matanzas administrativas" perpetradas por el nacionalsocialismo no podían sustentarse única y exclusivamente en fanáticos ideologizados, sino que el exterminio no habría sido del todo posible sin la colaboración de la población, personas normales y corrientes que, bajo una serie de determinadas circunstancias, estuvieron dispuestas a cualquier cosa. Arendt ponía así en duda la perversitas kantiana, la corrupción de raíz del corazón humano, dado que los crímenes más horrendos conocidos por la humanidad habían sido cometidos por personas movidas por las consideraciones más mundanas y ordinarias. El mal no podía entonces ser radical en el sentido que anteriormente le había atribuido, sino que el hecho de que personas sin pretensiones de maldad hubieran podido llevar a cabo los peores actos probaría que no existe componente malvado alguno en el seno de la naturaleza humana. No solo el juicio a Eichmann, sino que otros procesos, como los de Nüremberg, los de Frankfurt ${ }^{54}$, los realizados a antiguos miembros de la Gestapo, las SS o a figuras como Franz Stangl, habían corroborado que el ser humano no era ningún tipo de demonio, sino que en la

52 Zimbardo, P., El efecto Lucifer, Barcelona, Paidós, 2008, p. 383.

53 Young-Bruehl, E., Hannah Arendt. Una biografía, op. cit., p. 424.

${ }^{54}$ Los Juicios de Frankfurt — menos conocidos que los de Nüremberg (1945)—, fueron realizados entre 1963 y 1965 contra 22 antiguos oficiales nazis por los crímenes cometidos en el campo de concentración de Auschwitz. 
mayoría de los casos eran factores superficiales los que determinaban su comportamiento y dependía de causas triviales que añadieran o no al genocidio sus propias atrocidades personales ${ }^{55}$. Por este motivo, Arendt trataba de prevenir contra la tentación de generalizar acerca de la supuesta "perversidad de la naturaleza del hombre", puesto que dentro del sistema de exterminio nazi cualquier persona, llámese Eichmann, Stangl o como fuere, podía decidir por sí mismo ser bueno o malvado, de la misma manera que los que se opusieron al régimen de Hitler habían seguido el dictado moral de sus conciencias con todas sus consecuencias. Eso sí, la responsabilidad que, pese a todo, seguían teniendo las personas que participaron, activa o pasivamente en el Holocausto, muestra cómo la idea acerca de la imputabilidad que había desarrollado Kant — por la cual, nuestra voluntad es radicalmente libre a la hora de emprender nuestros actos y, por ende, somos responsables de ellos en tanto en cuanto somos agentes morales- sigue estando vigente en este pensamiento.

\section{Dos caras de la misma moneda: "mal radical" y"banalidad del mal"}

Sin embargo, aunque Arendt mantuvo su postura sobre la "no-radicalidad del mal", el hecho de que nunca desarrollase una argumentación minuciosa y completa acerca de la banalidad del mal ni proporcionase más ejemplos que el de Eichmann plantea una serie de dudas y de cuestiones pendientes que jamás fueron resueltas por la pensadora alemana. En primer lugar, parecía tener "ciertas reservas en cuanto a la generalidad de su tesis, pues en una ocasión le dijo a Mary McCarthy [...] que opinaba que Reinhard Heydrich [...] era el mal absoluto" ${ }^{56}$. Por otra parte, en su célebre réplica al historiador israelí Gershom Scholem — quien previamente había arremetido duramente contra Arendt por la publicación de Eichmann en Jerusalén- expone cómo el mal, lejos de estar enraizado en un defecto incomprensible y original del ser humano, carece de toda profundidad y se encuentra tan solo en la superficie, desafiando con ello al pensamiento; no niega la existencia de la maldad, sino que esta sea radical, es decir, no tiene unas raíces profundas y ocultas, sino que iría asociada a la superfluidad.

\footnotetext{
55 Young-Bruehl, E., Hannah Arendt. Una biografía, op. cit., p. 460.

56 Ibid., p. 463. Mary McCarthy fue una de las más íntimas amigas de Hannah Arendt, con la que mantuvo además una larga correspondencia. Por otra parte, Reinhard Heydrich fue el principal oficial nazi que diseñó la "Solución Final". Su fanatismo fue tal que, después de su asesinato en 1942 a manos de la resistencia checoslovaca, los nazis bautizaron como "Aktion Reinhard" (“Operación Reinhard”) el procedimiento para asesinar a los judíos del Gobierno General de Polonia mediante la instauración de campos de exterminio y que terminó con más de 1.750.000 judíos muertos.
} 
En conclusión, permíteme referirme al único asunto en que no me has interpretado mal y que me agrada que hayas planteado. Tienes mucha razón: he cambiado de opinión y no hablo ya de "mal radical". [...] Ahora, en efecto, opino que el mal no es nunca "radical", que sólo es extremo, y que carece de toda profundidad y de cualquier dimensión demoníaca. Puede crecer desmesuradamente y reducir todo el mundo a escombros precisamente porque se extiende como un hongo por la superficie. Es un "desafío al pensamiento", como dije, porque el pensamiento trata de alcanzar una cierta profundidad, ir a las raíces y, en el momento mismo en que se ocupa del mal, se siente decepcionado porque no encuentra nada. Eso es la "banalidad" 57.

Esta respuesta, junto a la afirmación realizada a McCarthy, según la cual "la frase «la banalidad del mal» contradice la frase que empleé en el libro sobre el totalitarismo: "el mal radical»" 58 , pueden resultar confusas, pues nos llevarían a deducir que todo mal es banal, cuando no es así. Pese a que fue la propia Arendt quien, de su puño y letra, dio pie a una malinterpretación acerca de un cambio determinante y fundamental en su manera de entender el mal, lo que encontramos en una observación más profunda - quizá ajena incluso para la propia autora - es una especie de continuidad entre la idea del mal radical y la banalidad del mal, en la que Arendt habría realizado únicamente un cambio de enfoque; esto es, solo habría variado el énfasis que concedía en cada caso a la explicación de qué era lo que posibilitaba o permitía el mal del nazismo. La noción central de su análisis pasa así de la "superfluidad" que caracterizaba al mal radical a la "irreflexión" propia de la banalidad del mal: mientras que en Los orígenes del totalitarismo trataba de entender la influencia de la ideología, la carencia de precedentes o qué motivos habían podido llevar a semejante horror, a partir de Eichmann en Jerusalén centra su esfuerzo en comprender cómo personas normales pudieron llevar a cabo acciones monstruosas —relegando con ello la importancia de los fanáticos nazis en el exterminio_- No obstante, esto no quiere decir que la banalidad del mal corrija la tesis del mal radical o que ambas ideas sean contradictorias entre sí — pese a lo afirmado por la misma Arendt_-; por el contrario, la superfluidad del mal radical es compatible con la carencia de profundidad del pensamiento expuesta en la banalidad del mal. Cuando Arendt vio a Eichmann comprendió que, efectivamente, no había que remitirse o buscar motivos malignos humanamente comprensibles para dar cuenta de los desastres cometidos por el III Reich, sino que estos podían ser también causados inconscientemente — debido a la carencia de una facultad autónoma crítica y de juicio_-, sin pretensiones malévolas o por intenciones superficiales.

\footnotetext{
57 Arendt, H., Escritos judios, Barcelona, Paidós, 2009, p. 575; Una revisión de la historia judía y otros ensayos. Barcelona, Paidós, 2015, pp. 149-150.

58 Arendt, H. \& McCarthy M., Entre amigas, Barcelona, Lumen, 2006, p. 240. Sin embargo, a continuación Arendt vuelve a eludir la cuestión: "El tema es demasiado difícil como para que yo pueda tratarlo aquî".
} 
La compaginación entre ambas posturas se puede apreciar en varios aspectos. En primer lugar, tanto la banalidad del mal como el mal radical se alejan de la arraigada noción, histórica y literariamente, por la cual el mal es entendido como expresión de malas voluntades o motivos malvados:

Este alejamiento de la tradición es lo que resulta perturbador en su análisis de la banalidad del mal. Pero, en este sentido, ya dijo lo mismo sobre el mal radical: no es una cuestión de "motivaciones malvadas", sino más bien un intento de "erradicar el concepto de ser humano", de volver a los seres humanos superfluos en tanto que seres humanos ${ }^{59}$.

En segundo lugar, la ausencia de razones subjetivas para la ejecución de actos terribles puede compatibilizarse con una participación masiva y organizada en el mal e incluso puede resultar útil para llevarlo a cabo con eficacia; es decir, "la participación constante en el mal puede convivir con la falta de una intención personalizada por provocar ese mal" ${ }^{60}$. La banalidad del mal encuentra así un encaje dentro del mal radical engendrado por el totalitarismo, pues este "precisa de una cierta normalidad ambiente para la realización de sus cometidos, y propende también a cierta normalización funcional de sus propósitos ideológicos y de las prácticas concordes de persecución, eliminación" ${ }^{61}$. De este modo, el éxito de un sistema totalitario como el nacionalsocialista se fundamenta sobre la base de personas normales y corrientes, hombres grises como decía Browning, que no asumen una implicación personal y directa con su tarea en la destrucción, sino que conciben su trabajo como una labor en la que se limitan a "cumplir órdenes" de sus superiores, descargando sobre ellos cualquier tipo de responsabilidad y cargo de conciencia. En suma, podemos extraer de este razonamiento dos conclusiones: primera, que el mal radical pudo operar gracias a la colaboración de personas corrientes y que "se sostiene sobre tejidos de normalidad en que se mueven existencias normales" ${ }^{62}$; y segunda, que el término "mal absoluto" o "mal radical" podría seguir empleándose para describir los crímenes del nacionalsocialismo.

Por último, las nociones de mal radical y de banalidad del mal destacan el propósito totalitario de aniquilar la humanidad del ser humano así como sus capacidades de pensamiento, juicio y reflexión. Son las dos caras del horror causado por el totalitarismo: el primero muestra la voluntad de llevar a cabo el proceso de deshumanización, de acabar con la condición humana tal y como la conocemos,

\footnotetext{
59 Bernstein, R., “¿Cambió Hannah Arendt de opinión? Del mal radical a la banalidad del mal”, op. cit., pp. 252-253; el destacado es del propio Bernstein.

${ }^{60}$ Birulés, F. (Ed.), Hannah Arendt: el legado de una mirada, Madrid, Sequitur, 2008, 159.

${ }^{61}$ Ibid., p. 161.

62 Ibid., p. 162.
} 
de hacer a los hombre superfluos, mientras que el segundo refleja las consecuencias que conlleva la abdicación de aquellas facultades que nos permiten discernir entre el bien y el mal para pasar a ser esclavos de una obediencia ciega ante una autoridad cruel y despótica.

\section{Conclusión}

Como podemos ver, el pensamiento de Hannah Arendt sobre la cuestión del mal resulta sumamente fructífero a la par que controvertido, suscitando un debate que permanece aún inconcluso. La filosofía de Kant, o al menos la interpretación que hizo acerca de la responsabilidad, la imputabilidad, la libertad de la voluntad o la disposición de la naturaleza humana hacia el bien o hacia un mal radical permea sus reflexiones, pese a que ella misma insistió en haberse alejado de la posición kantiana. En todo caso, sus esfuerzos se dirigieron a comprender las nuevas formas y manifestaciones que el mal había adoptado durante el siglo xx: cómo había podido suceder lo que tuvo lugar en Europa; cómo pudo surgir, ascender e instaurarse un régimen asesino como había sido el nacionalsocialista $-\mathrm{y}$ el estalinista - en el que millones de personas cooperaron, activa o pasivamente, en sus crímenes; cómo pudieron cristalizar aquellos elementos que acabaron dando pie al gobierno de Hitler, a los campos de concentración y de exterminio, a la matanza fría y sistemática de millones de inocentes, ante la impasible mirada del resto del mundo; cómo fue posible que el ser humano, desde fanáticos fervientes de ideología a personas comunes y ordinarias, con sus actos, permitiese la entrada del Infierno en la Tierra; en resumen: ¿por qué? Un ejercicio de comprensión que, en contra de lo que muchos -incluso dentro de su círculo más próximo- le reprocharon, o siguen todavía hoy recriminándole, no suponía en modo alguno un intento de justificación, sino de prevención. Únicamente conociendo y comprendiendo nuestra historia podremos estar prevenidos frente a los desastres y tragedias que esta trae consigo, evitando recaer en antiguos errores. Situarnos en una posición cognoscitiva de privilegio, por la cual creamos estar a salvo de las barbaridades del pasado porque "nosotros nunca actuaríamos asi", no hace sino volvernos más vulnerables ante las situaciones extremas y las tentaciones del mal, que revisten cada vez diferentes aspectos. Únicamente nuestro pensamiento, esto es, nuestra facultad autónoma de crítica, de reflexión y de juicio, que nos permite seguir profundizando y deliberando sobre la cuestión del mal, puede ayudarnos a impedir nuevos desastres. Como la propia Arendt dijo en 1973, en una de sus últimas entrevistas: 
Todo ser humano, en cuanto ser pensante, puede reflexionar como cualquier otro y juzgar por sí mismo, si así lo quiere. ¿Cómo incitarle a que quiera? No lo sé, no soy... lo único que puede ayudarnos, creo, es sencillamente reflexionar. Y pensar siempre significa pensar criticamente. Cualquier pensamiento mina lo que pueda haber de normas rígidas, de convicciones generales, etc. Todo lo que ocurre en el pensar está sometido al análisis crítico de lo que hay. Esto es: no hay pensamientos peligrosos, por la sencilla razón de que pensar ya es por sí mismo una empresa peligrosa. No pensar es aún más peligroso. No digo que pensar no sea peligroso, pero no pensar es aún más peligroso ${ }^{63}$.

${ }^{63}$ Ibid., p. 188. El destacado es mío. 


\section{Referencias Bibliográficas}

Arendt, H., Entre el pasado y el futuro, Barcelona, Península, 1996.

Arendt, H., Ensayos de comprensión 1930-1954, Madrid, Caparrós Editores, 2005.

Arendt, H., Escritos judios, Barcelona, Paidós, 2009.

Arendt, H., Lo que quiero es comprender, Madrid, Trotta, 2010.

Arendt, H., Los origenes del totalitarismo, Madrid, Alianza, 2010.

Arendt, H., Eichmann en Jerusalén, Barcelona, DeBolsillo, 2011.

Arendt, H., La condición humana, Barcelona, Paidós, 2015.

Arendt, H., Responsabilidad y juicio, Barcelona, Paidós, 2015.

Arendt, H., La vida del espiritu. Barcelona, Paidós, 2015.

Arendt, H., Una revisión de la historia judía y otros ensayos. Barcelona, Paidós, 2015.

Arendt, H. \& Jaspers, K., Correspondence 1926-1969 (Kohler, L. \& Saner H eds.), Orlando, Harcourt Brace Jovanovich, 1992.

Arendt, H. \& McCarthy M., Entre amigas, Barcelona, Lumen, 2006.

Bernstein, R., “'Son todavía relevantes las reflexiones de Arendt sobre el mal?”, en Revista Al Margen, no 21 y 22, 2007, pp. 49-63.

Bernstein, R., “¿Cambió Hannah Arendt de opinión? Del mal radical a la banalidad del mal”, en Birulés, F. (Comp.), Hannah Arendt: el orgullo de pensar, Barcelona, Gedisa, 2009, pp. 235-257.

Bernstein, R., El mal radical, Buenos Aires, Prometeo Libros, 2012.

Birulés, F. (Ed.), Hannah Arendt: el legado de una mirada, Madrid, Sequitur, 2008.

Browning, C.R., Aquellos hombres grises, Barcelona, Edhasa, 2002.

Di Pego, A., "Las concepciones del mal en la obra de Hannah Arendt. Crítica de la modernidad y retorno a la filosofía", en Revista Al Margen, no 21 y 22, 2007, pp. 88-103. 
JASPers, K., "El mal radical según Kant", Conferencias y ensayos sobre historia de la filosofia, Madrid, Gredos, 1972, pp. 141-164.

Jaspers, K., El problema de la culpa, Barcelona, Paidós, 1998.

Kant, I., Crítica del Juicio. Madrid. Tecnos, 2007.

Kant, I., Fundamentación para una metafísica de las costumbres, Madrid, Alianza, 2008.

Kant, I., La religión dentro de los límites de la mera Razón, Madrid, Alianza, 2009.

Kant, I., "Ideas para una historia universal en clave cosmopolita", en Ideas para una historia universal en clave cosmopolita y otros escritos sobre Filosofía de la Historia, Madrid, Tecnos, 2010.

Kant, I., Crítica de la razón práctica, Madrid, Alianza, 2011.

LeIva, J., "Modalidades del mal durante el nacionalsocialismo", en Quaderns de filosofia, vol. v, n ${ }^{\circ}, 2018$, pp. 11-28.

Levi, P., Trilogía de Auschwitz, Barcelona, El Aleph, 2012.

Marrades, J., "La radicalidad del mal banal", en Logos. Anales del Seminario de Metafísica, vol. 35, 2002, pp. 79-103.

Milgram, S., Obediencia a la autoridad, Bilbao, Desclée De Brouwer, 1980.

Sereny, G., Desde aquella oscuridad, Barcelona, Edhasa, 2009.

Weber, M., El politico y el cientifico, Madrid, Alianza, 2004.

Young-Bruehl, E., Hannah Arendt. Una biografía, Barcelona, Paidós, 2006.

Zimbardo, P., El efecto Lucifer, Barcelona, Paidós, 2008.

Bajo Palabra. II Época. No 22. Pgs: $57-80$ 